\title{
Research of Patent Race of Mobile Publishing and Press Innovation
}

\author{
Hejie Chen ${ }^{1,2}$ \\ ${ }^{1 .}$ School of Economic and management \\ Beijing Institute of Graphic Communication \\ 2. School of Economics and Management BUPT \\ Beijing University of Posts and Telecommunication \\ Beijing, China \\ chenhejie81@sina.com
}

\author{
Qiang Yan \\ School of Economics and Management BUPT \\ Beijing University of Posts and Telecommunication \\ Beijing, China \\ buptyan@gmail.com
}

\begin{abstract}
With the rapid development of wireless Internet and WIFI, mobile terminals have become an important media of content publishing. Mobile publishing ushered in the great development opportunity. But there is no authoritative definition of mobile publishing. This paper firstly presented a kind mobile publishing based on Web 2.0 environment. And the paper described mobile publishing chain and the press, magazine and newspaper' functions. According to our research, content quantity and quality available to users are important factors affecting the good development. Although the press, magazine and newspaper are important content providers, they lost many rights and profits in the whole industry chain. Since mobile publishing and information technology have a close relationship, we consider that the press, magazine and newspaper actively participated in patents and patent race. The paper presented that patent race improved enterprise innovation.
\end{abstract}

Keywords-Mobile publishing; Patent race; Patent

\section{INTRODUCTION}

With the rapid development of Internet and mobile Internet, digital reading took on an explosive growth. The rate of digital reading constantly increased. According ten national reading survey, the rate of digital reading was $40.3 \%$ in 2012, which it increased $1.7 \%$ than in 2012 [1].

The rapid development of mobile reading promoted the mobile publishing industry development. However, the press, magazine and newspaper didn't control the industry chain. As a young industry, the press, magazine and newspaper are important content providers, but they lost many rights and profits in the whole industry chain.

Since mobile publishing and information technology have a close relationship, we consider that the press magazine and newspaper actively participated in patents and patent race.

The paper is structured as follows. Section II provided mobile publishing concept. Section III introduced the mobile publishing industry chain and the press functions. Section IV outlined patent race improved the press innovation.

(The press, magazine and newspaper abbreviated the press as followings.)

\section{Mobile Publishing Definition}

So far, there is no authoritative definition of mobile publishing. Some research presented different concepts from self-domain. Mobile publishing is the mobile communication platform of press that can select book subject, edit content, publish, disseminate information, promote, market and aftersales service [2].The concept is defined from press domain. It emphasized on the mobile device completed the work process of press.

Mobile publishing is digital creating content process of books, newspapers, magazines and other content resource (for example, literary website).Digital resource management (DRM) is used to digital copyright protection. Digital content disseminate through the Internet, wireless networks, and storage devices. Users used the mobile devices to read or listen to the contents by software in anytime, anywhere [3].

This definition reflected the important parts of mobile publishing.

Firstly, providers of various content resources are traditional presses, magazines, newspapers. Other resource providers are literary website (for example, Shengda).

Secondly, a variety of specialized techniques applied to digital publishing. DRM is typically used to digital copyright protection.

Thirdly, different type's mobile devices finished reading or listening to the contents. Kindel, iPad and iPhone are typical mobile devices.

Fourthly, the mobile network operators are China Mobile, China Telecom, China Unicom.

Finally, users read and listen to the content by online or download the contents.

Due to the rapid development of Internet and mobile Internet, Web2.0 replaced Web1.0. The important and distinctive feature of Web2.0 is user participation that influenced the definition and development patterns of mobile publishing. According to Web2.0, we proposed a definition of mobile publishing as follow. Mobile publishing is that text, images, sounds and other content converted digital content through rigorous editing system processing, and digital content abided by the laws and regulations, the digital processing, the appropriate technology completed copyright 
protection, digital content disseminated through the Internet, mobile Internet, the user used mobile devices and the corresponding reading software to read the text, listen to audio, watch video files and other functions. Meanwhile, users can participate in interactive publications and complete compliance with the requirements of their own personal customized publications.

\section{Mobile Publishing Industry Chain AND THE PRESS FUNCTIONS}

\section{A. Mobile Publishing Industry Chain}

Our team considered that mobile publishing industry chain included equipment providers, network providers, service providers, content integrators, terminal providers, users.

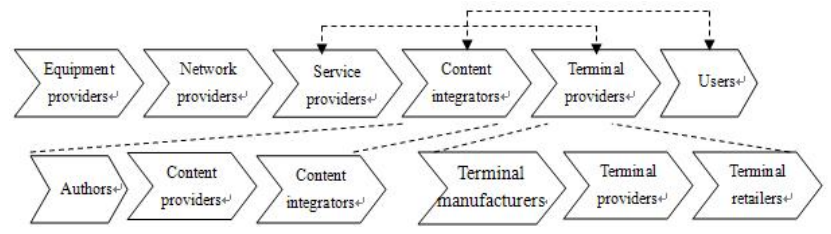

Figure 1. Mobile publishing industry chain

Services provided to users through menu and users pay according to information flow. Services providers didn't necessarily use the telecommunication system. In many countries such as Japan and China, network providers and services providers are the same entities.

The authors didn't refer to traditional authors who subscribed a contract with the publishing, but also referred the online writers, etc. The authors are the original content creators which provided the texts, images, cartoons and other contents for other people reading. Authors own the copyright of self-writing. They devised writings to the content providers and usually paid more attention to writing, but sometime they can play the role of content providers

Content providers usually didn't the authors. Service providers provided the available content to users through the menu. And users paid according to traffic. Service providers didn't own basic network, but they charge users according to the protocol and billing system. Network providers and Service providers are same in many countries such as Japan, China. The content providers not only aggregated a large number of contents from independent authors, but also ensured the legitimacy and true of contents. When the contents are spreading, the content providers ensured that the contents are not being illegally copied in the end.

Content providers provided the content to user through the website. Content providers usually didn't the authors. SP usually act as the content providers. Content integrators mainly collected different content from diverse authors or content providers to integrate into a specific website. Content integrators are known as portal site. In theory they focused on contents compounding and didn't created their own content. Telecommunication operators acted content integrators. In many countries, but they in china wanted to do more things. China Mobile set up an R \& D base to create contents in Zhejiang.
Terminal manufacturers are responsible for the terminal production. Terminals usually are mass production. Terminal manufactures independently researched and produced terminals. Sometimes they produced terminals according to standards provided by telecommunication operators.

Terminal providers play the bridge between terminal manufactures and retailers. Terminal retailers sold terminals to the consumers. They are traditional retail stores or any roles legally sold terminals. Mobile terminals included mobile phones, electronic reader. They can provide on-line or off-line reading functions through the telecommunication network or wireless internet network.

The customers not only read all kind of contents from traditional books, but also from new media which included digital library, digital books, the networks and mobile devices. On the other hand, the customers wanted the products of reasonable price and better service quality. It is noteworthy that customer participation is becoming increasingly important.

\section{B. The Press Functions in the Mobile Publishing}

Now the press has not done enough to the mobile publishing development. The press must actively research, develop and lay down the mobile publishing criteria. And the press protected the core resource of mobile publishing-content and copyright. The press must immediately seek a benefit distribution mode and control the copyright of the mobile publishing. At the same time, the press intensified cooperation with the developer of mobile publishing platform.

\section{PATENT RACE IMPROVED THE PRESSES INNOVATION}

\section{A. Patent and Patent Race}

According to Wikipedia, the term patent usually refers to the right granted to anyone who invents any new, useful, and non-obvious process, machine, article of manufacture, or composition of matter [4].Patent divided into three categories: invention model patent, utility model patent and industrial design [5].

A patent race is defined as a simultaneous race between many teams, all searching for the same specific innovation and only one finds it first. Such patent races create duplication of innovative activity, which is Pareto-inefficient [6].

\section{B. Patent Race Improved Enterprise Innovation from the Strategic Level}

Currently the presses have realized that gained less profits relied solely on traditional paper media. It is an important development direction that the presses in collaboration with other enterprises improved the derivative products of content resources. Currently South Korea and Japan have a mature profit model of mobile publishing. The presses should research these cases from a strategic perspective. The presses should invest in new technologies that can bind the content research. And an important way to find a new technology development direction is familiar with patent architecture of mobile publishing. Specially the 
presses are conscious of the most intense part of the patent race, which are usually core technology and have maximum profit.

\section{Patent Race Improved Enterprise Innovation from the Tactical Level}

Human resource of traditional presses is editors and marketing persons. Patent race of mobile publishing required many talent employees of computer, mobile communication and law. Professional talent of different domain will change enterprise culture and improve enterprise quality. Mobile publishing force the press to propose new management style that promoted the presses' reform.

\section{Patent Race Provided a Partner Standard Establishing Strategic Alliances}

The presses knew built strategic alliances to improve their competitiveness.Patent pool essentially is strategic alliance. To combine content and information technology to produced patent must involve collaborating with a number of companies. The presses evaluated the power of enterprises participating in the patent race, found the fit enterprise. Enterprises taking part in the patent race is the essence of corporate partners. The process of patent race found the right strategic alliance to improve signification of mobile publishing chain.

\section{E. Trademark Value Improved the Presses Value}

The research of patent race proved that trademark value has a competitive advantage alternative in a highly competitive industry. We considered that applying for design patent and trademark is the easiest form of patent race and patent is the most convenient way to protect benefit of the press. In fact, many presses have many trademark that the most common are self-name and LOGO. Many pirates often illegally used of these resources. Another resources transformed trademark is a series books' name. The press published many series books every year. Some books became bestseller, but the press didn't apply for trademark and design patent. Other presses simply modified and copied content to gain profit.

\section{ACKNOWLEDGMENT}

Institute Level Projects Funded by Beijing Institute of Graphic Communication E-b-2012-07

\section{REFERENCES}

[1] Ten national reading survey, http://www.hnxwcb.com/web/zwdt/xydt/xyxw/04/23605.shtml

[2] Huang Chaoqin, Mobile publishing. Information on Publication, 2004(21), pp.21

[3] Zhu Yin, Mobile reading lights future publishing, China Publishing Journal, 2008(6), pp.59-60

[4] Patent (2014), http://en.wikipedia.org/wiki/Patent

[5] People's republic of china patent law, http://www.china.com.cn/chinese/zhuanti/zhshchq/759867.htm

[6] Joseph Zeira, Innovations, Patent Races and Endogenous Growth, http://www.intertic.org/Theory\%20Papers/Zeira.pdf. 